\begin{tabular}{|l|l|l|}
\hline \multicolumn{2}{|c|}{ PublisherInfo } \\
\hline \hline PublisherName & $:$ & BioMed Central \\
\hline \hline PublisherLocation & $:$ & London \\
\hline \hline PublisherImprintName & $:$ & BioMed Central \\
\hline \hline
\end{tabular}

\title{
Bcl-3 gene is involved in T cell survival
}

\begin{tabular}{|l|l|l||}
\hline \multicolumn{2}{|c|}{ ArticleInfo } \\
\hline \hline ArticleID & $:$ & 4070 \\
\hline \hline ArticleDOI & $:$ & $10.1186 /$ gb-spotlight-20010501-01 \\
\hline \hline ArticleCitationID & $:$ & spotlight-20010501-01 \\
\hline \hline ArticleSequenceNumber & $:$ & 141 \\
\hline \hline ArticleCategory & $:$ & Research news \\
\hline \hline ArticleFirstPage & $:$ & 1 \\
\hline \hline ArticleLastPage & $:$ & 2 \\
\hline \hline & & RegistrationDate : 2001-05-01 \\
ArticleHistory & $:$ & OnlineDate $\quad$ 2001-05-01 \\
\hline \hline ArticleCopyright & $:$ & BioMed Central Ltd2001 \\
\hline \hline ArticleGrants & $:$ & \\
\hline \hline ArticleContext & $:$ & 130592211 \\
\hline \hline
\end{tabular}




\section{Tudor Toma}

Email: ttoma@mail.dntis.ro

Apoptotic death of lymphocytes is a critical process in limiting the extent and duration of immune responses but little is known about the mechanisms by which this occurs. In the May Nature Immunology, Thomas Mitchell and colleagues from the National Jewish Medical and Research Center, Denver show that adjuvants may improve survival of activated T cells via induction of the Bcl-3 gene.

Mitchell et al used a microarray to compare gene expression in $\mathrm{T}$ cells activated either with antigen alone or antigen in the presence of two different adjuvants (VV or LPS). Both adjuvants increased Bcl-3 expression. Retroviral infection experiments showed that expression of Bcl-3 increased survival of activated T cells in vitro and in vivo (Nat Immunol 2001, 2:397-402).

Bcl-3 is a member of the I?B subfamily of inhibitors. This subfamily is part of the NF-?B transcription factor protein family and it is suggested that a balance in the concentration of various NF?B family members regulates apoptosis and survival of activated $\mathrm{T}$ cells.

\section{References}

1. Mitchell TC, Hildeman D, Kedl RM, Teague TK, Schaefer BC, White J, Zhy Y, Kappler J, Marrack P: Immunological adjuvants promote activated T cell survival via induction of Bcl-3. Nat Immunol 2001, 2:397-402., [http://www.nature.com/ni/]

2. National Jewish Medical and Research Center, [http://nationaljewish.org/main.html]

3. Gerondakis S, Strasser A: To live and let die. Nat Immunol 2001, 2:377-379., [http://www.nature.com/ni/] 